\title{
Reward strategies and job satisfaction in private companies: a case of Uganda Breweries- Luzira
}

\author{
Boniface Okello Ochwo ${ }^{1^{*}}$, David Mwesigwa ${ }^{2}$ \\ Discipline of Public Administration and Management, Uganda Christian University, Uganda ${ }^{1}$ \\ Discipline of Public Administration and Management, Lira University, Uganda ${ }^{2}$ \\ boniochwo@yahoo.com ${ }^{1 *}$, dmwesigwa@lirauni.ac.ug ${ }^{2}$
}

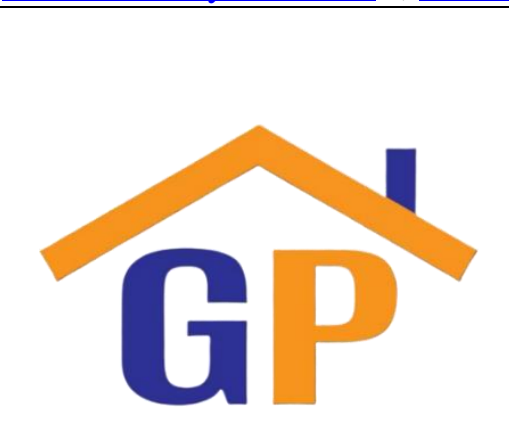

Article History

Received on 22 January 2021

$1^{\text {st }}$ Revision on 28 January 2021

$2^{\text {nd }}$ Revision on 1 February 2021

Accepted on 2 February 2021

\begin{abstract}
Purpose: This study aimed to determine the relationship between reward structures and employee job satisfaction at Uganda Breweries, Port Bell in Luzira.
\end{abstract}

Research methodology: It was cross-sectional, quantitative though involving qualitative elements. The study involved 150 respondents sampled using purposive and convenience sampling strategies. Data was collected using a self-administered questionnaire and an interview guide. The findings reveal a significant positive relationship between financial rewards structures and employees' job satisfaction at Uganda Breweries.

Results: The findings suggest a significant positive relationship between non-financial rewards structures and employees' job satisfaction at Uganda Breweries Port Bell at Luzira. The findings further advocate for enhanced attention linking promotions to job satisfaction of employees at Uganda Breweries. It is concluded that financial rewards, non-financial reward strategies and promotions had a highly positive significant relationship on employee job satisfaction at Uganda Breweries-Luzira.

Limitation: This study was limited to Uganda Breweries at Port Bell, a private company and so its findings may not easily be generalised across organisations.

Contribution: The results can be useful to private-sector managers.

Keywords: Financial rewards, Non-financial reward, Job satisfaction, Decision-making, Income

How to cite: Ochwo, B. O., \& Mwesigwa, D. (2021). Reward strategies and job satisfaction in private companies: a case of Uganda Breweries-Luzira. Annals of Human Resource Management Research, 1(1), 69-83.

\section{Introduction}

Bernard (2012) identified that no subject in the history of management had had a great controversy about job satisfaction and how it is influenced by motivation. Since the early behaviourists, the two subjects move closely without employees' effective motivation; their satisfaction on the job turns down. Olasimbo and Onabanjo (2012) pointed out that job satisfaction is essential to an organisational setting's long-term growth. Maicibi (2003) suggested that studies and experiments of later scholars in management, sociology and psychology suggested that motivating employees will on the job contribute to high job satisfaction increasing their productivity levels on the job. Therefore, motivation was established to increase on employees' commitment, hence a high sense of satisfaction on the job. With the above brief historical review several researchers have attempted to relate satisfaction of employees on various independent variables, for instance, Kalyango and Eckler (2010) studied about head teachers leadership styles and job satisfaction of government instructors aided primary colleges in Mpigi District while Nassolo (2008) studied about motivation and job satisfaction of employees in monitor 
publications limited and found out that financial motivation significantly related with employees job satisfaction. However, in all those studies, none was relating rewards structures to employees' satisfaction in Breweries Limited at Port Bell Luzira.

This study was guided by two theories Herzberg Two Factor Theory and the Equity Theory. The study was guided by Hertzberg two factor theory propounded by Armstrong (2009). The theory states that satisfaction and dissatisfaction at nearly arose from two different factors: hygiene, control, social relationships, working conditions, and remuneration. Hygiene issues are those whose dearth leads to dissatisfaction. Examples of these are salaries, good accommodation, welfare, treatment, transport, and psychological support. The motivators on the job consist of, achievement, the work, recognition challenging work, progress, as well as growth in the job. In this study it was theorised that to yield satisfaction of staff hygiene factors which consider utilisation of, resources like, teaching resources, financial resources, time and human resources salaries should be provided adequately basing on the professional needs. Failure to provide financial and non-financial rewards' effectively as required implied that satisfaction of lecturers on the job would go down. This makes the theory relevant to relate the study variables. To realise the high satisfaction of employees they have to be rewarded using both the hygiene satisfier factors which encompasses monetary rewards and dissatisfaction, including nonfinancial motivation and promotions on the job.

The Equity theory developed by Adam Stancy in 1965 cited in Ngethe, Iravo and Namusonge (2012), states that employees at work should be rewarded differently but equitably depending on one's level of inputs in the organisation. Basing on this theory employees compare what they receive in relation to inputs of other similar employees doing the same kind of work. Tibamwenda (2010) notes that employees compare what they earn in relation to what employees doing similar jobs in another organisation earn. If they find out that they are cheated in relation to what others earn in financial and non-financial means, their job retention reduces. However, when they compare and find out that they are not cheated, their job retention increases. Okumbe (1999) further pointed out that if employees discover that there is inequity in rewards administered, their satisfaction with the organisation reduces. Desmond (2012) stated that employees' motivation depends on the perceived association between performance and outcomes of the individual. Mawoli and Babandako (2011) suggested that the equity theory advocates that people are enthused when they discover themselves in circumstances of fairness. According to Adams (1963) inequality happens when an individual takes more or less than the individual considers is merited based on their contribution. Basing on this theory employees doing the same kind of work Basing on this theory employees be rewarded fairly, but differently according to their inputs in the company. Any case of unfairness in the rewards received would cause dissatisfaction at work and the reverse is true. This made the theory relevant to the study.

The independent variable in this study was rewards defined by Maicibi (2003) as the ambition that energises people to act or not in a certain manner. In this study reward strategies involved financial reward strategies including salaries earned, wages and pay benefits on the job, non-financial reward strategies including praises, recognition, responsibility, and promotions. It further involved motivation of employees through promotion reward strategies involving, transfers, assigning higher responsibilities and demotions. This study's dependent variable is job satisfaction defined as a gratifying expressive condition occasioning from the assessment of one's contribution (Roos, 2003). However, Banard (2012) defined job satisfaction as the magnitude to which one enjoys their job. In this study, the contentment of employees encompasses satisfaction with the strategies, responsibilities, job security, and commitment to work.

The study was contextually carried out in Uganda Nile Breweries located at Port Bell Luzira approximately 7.1 miles on road, South-East of the Central Business District (CBD) of Kampala capital city. According to the Uganda Breweries-Luzira Annual Performance Report of 2010 - 2011 employees were highly dissatisfied with their work in the company. Many of these employees were not strongly committed at work, were not fully attached to work and above all were not happy with their job. Although several factors might have contributed to this poor job satisfaction of employees on the job, 
this study was primarily interested in establishing how rewards structures relate to employees' satisfaction on the job in Uganda Breweries Limited.

\section{Problem statement}

Several strategies like salary reviews, giving benefits and appraising staff have been put in place to increase satisfaction of employees on their job. However, according to Annual performance Report of Uganda Breweries for the period 2010 - 2011, it was found out that many of the employees were still not yet satisfied on their job. Many employees identified that they were not fully committed at work, were not happy with the roles and policies in place and felt insecure at work, which negatively impacted their satisfaction and performance. There were severe cases of dissatisfaction with the policies in place; many of the employees were feeling insecure with their job since they did not have appointment letters. It was anticipated that if this dissatisfaction continues the company will be affected negatively. The company's production rate was expected to go down and it is expected that employees may not stay on the job longer. Although several factors contributed to this low satisfaction of employees at work, this study explored how reward structures relate with employee satisfaction at Uganda Breweries-Luzira.

\section{Purpose and objectives of the study}

The study aimed to determine the relationship between reward structure and employee satisfaction at Uganda Breweries-Luzira. Consequently, the study sought to: find out the relationship between financial reward structures and employee satisfaction at Uganda Breweries-Luzira; determine how nonfinancial reward structures relate with employee satisfaction at Uganda Breweries-Luzira; and determine how promotion reward structures relate with employee satisfaction at Uganda BreweriesLuzira.

\section{Literature review}

\subsection{Theoretical review}

The study was guided by Hertzberg two factor theory propounded by Fredrick Hertzberg in 1959 cited in both Jennifer and Gareth (2006) and Armstrong (2009). The theory suggests that satisfaction and dissatisfaction emerge from different factors, that is, the hygiene (supervision, interpersonal relations, working conditions and salary). The theory clusters human needs into hygiene factors and motivating factors. Hygiene factors are those whose absence results into frustration. For example, prompt payment of remunerations, decent housing, welfare packages, transport, and emotional support. The job's motivators consist of; achievement, the work itself, acknowledgement, stimulating work, progression, and growth on the job. In this study, it was hypothesised that to achieve satisfaction, hygiene factors which consider monetary, non-monetary and advancements should be provided basing on the professional needs. However, failure to provide financial and non-financial reward strategies' effectively as required implied that employees' satisfaction would go down. This makes the theory relevant to relate the study variables. To realise the high satisfaction of employees they have to be motivated using both the hygiene/satisfier factors which encompasses monetary rewards and the dissatisfaction, which includes the non-financial motivation and promotions on the job. Mawoli and Babandako (2011) suggested that satisfaction and dissatisfaction factors offer hygienic and conducive working environment which can either eliminate or encourage workers' grievances regarding the conditions at work. The second theory that was used in this study was Stacy Adams Equity theory cited in Maicibi (2003). It suggests that employees should be compensated equitably basing on their contributions to an organisation. In case employees are rewarded equitably by ensuring that monetary and non-monetary incentives are provided to employees as required, their satisfaction on the job increases and the reverse is true.

\subsection{Monetary reward strategies and satisfaction of employees}

Ng'ethei et al (2012) suggested that attractive remuneration especially monetary reward packages are essential aspects of satisfaction because they fulfil the monetary and material needs. Hong, Hao, Kimar, Ramendran, Kadiresan (2012) revealed that monetary motivation comprises money given to an employee as a return for injury, loss or grief; money received by an employee from an employer as salary or wages. Hong et al (2012) suggested that compensating employees on the job using the money and benefits such as pension, health insurance, retirement plans, and allowances provision of company 
cars for transportation creates high retention opportunities of employees on the job and failure to provide these creates employees to switch to other organisations which provide the same. This study will find out what benefits and how these benefits impacts on academic staff satisfaction.

These findings were supported by Musaazi (2005) who noted that there are three types of rewards which are expressed in monetary terms and administered to employees including wages, salaries and other monetary benefits offered to employees. Effective management of remuneration encourages and motivates employees. It suggested here that experienced human resource managers recognise that it takes more than a high salary to attract and satisfy employees. Mullins (2010) pointed out that workers can be inspired by obtaining the highest possible remunerations through working in the most efficient and satisfying way. Motivation is a simple issue; an employee's desires more than anything else are high remunerations. Mawoli and Babandako (2012) found out that academic staffs are motivated, at work, when the work environment is conducive. As a concept of motivation and subsequent approaches to motivation at work, rational economic needs have failed the enduring debate about monetary rewards as a motivator and their influence on employee job satisfaction. Jennifer and Gareth (2006) suggest that managers can choose among several merit pay plans depending on their work performance and other considerations. Individual job holders' pay within job categories is determined by factors such as performance, seniority and skill levels. Therefore pay in form of salaries, wages, enhances high job satisfaction of employees at work. Indeed, academic staff should be well paid, not on basis local servicetied rates (local salary scales) but on competitive international scales that are comparable to those given by similar institutions across borders and can make best and bright academic staff perform as predictable. In the 1990's, remuneration opportunities of academic staff have improved through enhanced salaries, from the Private Entry Scheme (PES) especially the perceived wet colleges that were generating a lot of revenue. However, none of the above studies and reviewed works was from the context of Uganda Breweries relating reward strategies and satisfaction of its employees which forms the study's basis.

\subsection{Non-monetary reward strategies and satisfaction of employees}

Maicibi (2007) suggests that non-monetary reward strategies include non-cash benefits in addition to basic pay. It includes camp time which is offered to an employee instead of money because he or she has worked for extra hours. Further, it includes achievement, offering employees challenging work and allowing them to advance on the job. Hong et al (2012) suggest that intrinsic and non-financial means of motivation that contribute to employee satisfaction include allowances which include company motorcars or subsidised transport. Tibamwenda (2010) notes that recognition for achievement, being accorded high status, praising an employee and experiencing a sense of accomplishment are great motivators. According to Heery and Noon (2001), non-monetary incentives bring about satisfaction, recognition; personal development at work and the social status of such employees are to be improved. They add that increasing attention to the use of non-monetary means of rewarding employees by management and recognition of award schemes is commonplace in many companies and are used to reenforce high job satisfaction. Maicibi (2003) affirms that non-monetary remuneration is remuneration that is not paid as part of wages or salaries. Its understanding is interesting because it suggests how different levels of employees regard these remunerations differently. Symbolic recognition such as plaques or coffee mugs with inscription can be effective, provided they reflect sincere appreciation to hard work hence high job satisfaction.

Communication and reinforcement of good behaviours daily through recognition by the immediate management, for example, a thank-you, notes of appreciation, a pat on the back, is pivotal in enhancing satisfaction, thereby increasing the worker's sense of commitment. Monetary or tangible rewards can have little impact on behaviour without the intangible positive reinforces, such as managerial praise, peer recognition, and appreciation coupons (Wertheimer, 1970). These are positive reinforcers and if applied on spot play an important role in providing immediate reinforcement for desired behaviours. Once a desired performance is consistently rewarded, the corresponding pattern of recognition can become sporadic as the preferred behaviour becomes routine with employees since they will be satisfied on the job (Nelson, 1994). However, that study was conducted in the western world where conditions are different from that of employees at Uganda Breweries. Recognition of nurses can improve their 
satisfaction (Cronin \& Becherer, 1999). Employee recognition produces motivation and high employee satisfaction hence leading to low intent to leave. The best recognition is from immediate supervisors. Get started by encouraging and teaching managers how to recognise and reward employees. Rewards do not need to be large (high dollar value) but something tangible and fun is good (Ulrich et al., 1999). Verbal praise formal or written as well as social and symbolic recognition do not have a high monetary value but have been given the cold shoulder and managers have concentrated on the monetary aspects to foster employee satisfaction. Since this study is not on nurses' satisfaction, it gives way to determine how non-monetary rewards contribute to employee job satisfaction at Uganda Breweries. Mullins $\underline{(2010)}$ reveals that training is necessary to ensure an adequate supply of technically and socially competent employees and capable of career advancement into specialist departments or management positions. Therefore, there is a continual need for the process of staff development and training to fulfil an important part of this process.

Ngobeni and Bezuidenhout (2011) note that in situations where organisations fail to give employees skills required, satisfaction levels tend to diminish. Consequently, career plans have to consider a wide range of training opportunities like study leaves and workshops for employees to gain skills that will make them highly satisfied. Naris and Ukpere (2009) suggest that organisations should focus on developing competences of their staff to adjust to changes that have been triggered by globalisation forces, owing to the fact that staff members in organisations are key resources. Staff training involves all activities, actions, processes, policies, programmes, and procedures employed to support staff to improve their satisfaction on the job to achieve goals. The provision of training, mentoring and effective review of training and development activities will enable organisations achieve their goals. Green $\underline{(1996)}$, contends that human beings are not only encouraged by money but also by social status. The design of an organisation's compensation system can then have important effects on its employees' overall motivation. This study looked into non-monetary incentives and how they influence job satisfaction of employees. However, none of the above works was from the context of Uganda Breweries regarding its employees' satisfaction hence this study.

\subsection{Promotion strategies and satisfaction of employees}

Tung et al (2018) suggest that the degree to which an employee sees their likelihood to grow through being promoted within the organisation is essential. Consequently, employees are contented to serve in careers that offer them prospects of being raised to higher and more puzzling positions. As such, Dockel $\underline{(2003)}$ notes that individuals need not be compensated monetarily but they should be presented with prospects to grow within the organisation. Employees who feel that they cannot rise above their positions, are not inspired and will not be pleased to keep performing as expected. Promotion offers opportunities to grow and it is one of Herzberg's factors which can be used to enhance employee job satisfaction. Mpaata (2009) identifies the way how a worker views the opportunity for advancement is important to how satisfied one is on the job. Promotional opportunities are important to workers job satisfaction. Schneider et al (1992) have noted that opportunities for promotion are essential for employee retention since employees who perceive few opportunities for progress develop a negative attitude towards work and the organisation. It is identified that employees consider their current jobs as stepping stones for other jobs. Promotion on the job is essential if well managed in that the employees' morale will improve and stimulate efficiency, thus motivating a staff to stay at work. Promotion of employees should be based on both superiority and excellence as criteria with no favouritism.

Nawaz, et al., (2012) notes that career development is a procedure proposed and aimed to tailor the needs of employees associated to their job as well as prospects of an organisation from its human capital so that both can realise a maximum level of satisfaction. Consequently, companies need proficient workers who can lead them to long-term success. Sandhya and Kimar (2011) underscore that career development programs aid when individuals are concerned about their career growth. Knowing one's career path in regard to their opportunities of promotion generates a sense of satisfaction at work. Tung et al (2018) suggest that when employees have a wide level of dissatisfaction with the promotion criteria, there is a likelihood of low job commitment in an organisation. It is because of this reason that several staff are reported to neglect their job. 


\section{Research methodology}

This study espoused a cross-sectional survey, seeing a detailed inquiry into an individual, group, institution and allows thorough examination of a particular issue (Prince, 1998). Data was gathered from a cross-section of diverse respondents at one point in time. This design helped to save time as well as reducing on the financial constraints. The target population was 163 employees and 25 administrative staff at Uganda Breweries; this included the production unit, sales department, marketing department, and accounts. The sample size was determined using the Krejcie and Morgan's table (Sarantakos, 2005: 173). Consequently, the sample size was 150 respondents. Purposive sampling was adopted for top management staff while simple random sampling was used on general employees. In this study, questionnaires were used as a major data collection instrument since it is less expensive, saves time, and gives valid information (Xerri, 2017). Interviews were carried out on 15 top administrative staff to supplement the questionnaires.

The researchers conducted a repeated review of the instrument by carrying out a field pre-test (Apter \& Boorer, 1971). Validity was established through a validity test using content validity index (CVI). Two content experts were used to rate items set in the questionnaire after which a CVI was computed. To ensure reliability, the questionnaire was pre-tested on selected four respondents to ensure consistency and comprehensiveness. The degree of reliability was established using Cronbach's coefficient Alpha whose values from the various instrument sections were greater than 0.7 , suggesting that the instrument was reliable. Data were edited and coded to ensure accuracy and consistency. The analysis of interview responses and documentary reviews involved linking them to the variables under the study. The information from interviews was analysed using the content analysis method. The data collected through questionnaires were analysed using Statistical Package for Social Sciences version 18 (SPSS), focusing on central tendencies and dispersion measures and each of the objectives was tested using Pearson's Correlation Co-efficient index.

\section{Results and disscussions}

\subsection{Results}

The highest number of the respondents were aged 30-39 years $34.9 \%$, followed by those in the age group 20-29 years (30.3\%), few of the respondents were in the age group 40-49 years (14.7\%). This suggests that a good number of the employees at Uganda Breweries were below retirement age and this could be a source of their satisfaction to worker harder. $60.6 \%$ of respondents suggested they had a work experience of 6-10 years, followed by $23.9 \%$ with $11-15$ years experience, $8.3 \%$ had the experience of 16 or more years and $7.3 \%$ had the experience of $0-5$ years. These findings suggest that employees might be satisfied on the job since their job experience is fair. A big number of respondents were from the production department (31.1\%), followed by $29.3 \%$ from transport department, $15.6 \%$ from marketing and $8.3 \%$ were from the Human resource department. This shows an even distribution of employees among departments which can suggest that satisfaction would be reduced as workloads are low thus minimising job stress. The married (63.3\%) participated more in the study than the singles $(36.7 \%)$ were single. This shows that married employees have higher chances of being satisfied at work than the single employees. The higher number of the respondents was males (51.4\%) than females (48.6\%). These results suggest that most of the respondents are male in Nile Breweries at Luzira. It might also suggest that employers are satisfied with having married employees despite being affected by maternal problems at home. Most of the respondents were degree holders $(28.5 \%)$, followed by $23.9 \%$ who had completed secondary school, $20.2 \%$ holding a Diploma while $13.8 \%$ stopped at primary school. The findings reveal that employees at Uganda Breweries are educated for the job which might add on their job satisfaction.

\section{Level of satisfaction among employees of Uganda Breweries}

In this study, employees' satisfaction at Uganda breweries at Port Bell was operationalised into six quantitative items on which employees were requested to rate themselves basing on a scale ranging from 5=Strongly Agree, 4=Agree 3=Neutral, 2=Disagree and 1=strongly disagree . 
Table 1: level of satisfaction among employees

\begin{tabular}{|c|c|c|c|c|c|}
\hline \multirow{6}{*}{$\begin{array}{l}\text { Indicators } \\
\text { I am satisfied with the rules and } \\
\text { policies in place }\end{array}$} & Scale & Freq. & $\%$ & Mean & Std. Dev \\
\hline & Strongly disagree & 34 & 31.2 & & \\
\hline & Disagree & 18 & 16.5 & & \\
\hline & Neutral & 18 & 16.5 & 2.7706 & 1.53136 \\
\hline & Agree & 17 & 15.6 & & \\
\hline & Strongly agree & 22 & 20.2 & & \\
\hline I feel secure working at Uganda & Strongly disagree & 10 & 9.2 & & \\
\hline \multirow[t]{4}{*}{ Breweries } & Disagree & 30 & 27.6 & & \\
\hline & Neutral & 26 & 23.9 & 3.0642 & 1.19625 \\
\hline & Agree & 29 & 26.6 & & \\
\hline & Strongly agree & 14 & 12.8 & & \\
\hline \multirow[t]{5}{*}{ I am strongly attached to my work } & Strongly disagree & 07 & 6.4 & & \\
\hline & Disagree & 11 & 10.1 & & \\
\hline & Neutral & 32 & 29.4 & 3.4679 & 1.0764 \\
\hline & Agree & 42 & 38.5 & & \\
\hline & Strongly agree & 17 & 15.6 & & \\
\hline I feel happy working at Uganda & Strongly disagree & 04 & 3.7 & & \\
\hline \multirow[t]{4}{*}{ Breweries } & Disagree & 15 & 13.8 & & \\
\hline & Neutral & 24 & 22.0 & 3.6972 & 1.1507 \\
\hline & Agree & 33 & 30.3 & & \\
\hline & Strongly agree & 33 & 30.3 & & \\
\hline \multirow{5}{*}{$\begin{array}{l}\text { I feel a strong sense of belonging to } \\
\text { the Uganda Breweries }\end{array}$} & Strongly disagree & 12 & 11.0 & & \\
\hline & Disagree & 17 & 15.6 & & \\
\hline & Neutral & 21 & 19.3 & 3.3761 & 1.2822 \\
\hline & Agree & 36 & 33.0 & & \\
\hline & Strongly agree & 23 & 21.1 & & \\
\hline
\end{tabular}

Results from table 1 suggest that a higher number of respondents disagreed because they were contented with rules and policies in place $(47.7 \%)$ compared to $35.8 \%$ who agreed while $16.5 \%$ were impartial. This suggests that rules and policies do not favour every employee. $39.4 \%$ respondents agreed that they are secure at work compared to $36.7 \%$ who disagreed while $23.9 \%$ were neutral. This further suggests that employees are not secure at work. Over half of the respondents $(54.1 \%)$ agreed that they are strongly attached to work compared to $16.5 \%$ who disagreed while $29.4 \%$ were neutral. This suggests that employees at Uganda Breweries-Luzira are attached to their job. Majority of the respondents $(62.4 \%)$ agreed that they feel at home while at work compared to $10.1 \%$ who disagreed while $27.5 \%$ were neutral. Majority (60.6\%) agreed that they feel happy while at work compared to $17.5 \%$ who disagreed while $22 \%$ were neutral. This implies that employees at Uganda Breweries-Luzira are always happy at work. And, $54.1 \%$ of the respondents agreed that they feel a strong sense of belonging to the company compared to $26.6 \%$ who disagreed while $19.3 \%$ were neutral. This suggests that employees at Uganda breweries-Luzira feel a sense of belonging at work.

The cumulative percentages suggest that, in general, employees at Uganda Breweries-Luzira are satisfied on the job. The lowest mean was on the item "I am satisfied with rules and policies in place" mean $=2.7706$ and the highest mean was on the item "I feel happy at work" mean $=3.6972$. These mean values suggested that employees were satisfied on the job at Uganda Breweries-Luzira. The standard deviations were low with the highest being on security at work (Std. dev $=1.19625)$ and the lowest on feeling at home while at work (Std. dev $=.93084)$. This indicates that employees at Uganda Breweries-Luzira have similar opinions about their job satisfaction. These findings were in agreement with the views of a participant who said; 'I wish I could get satisfied with the work conditions and procedures. My immediate supervisor is too friendly with me and I get satisfied fully at work.' Thus suggesting that at times employees are satisfied with the work. Another participant noted that 'I am always happy at work since I am given tasks that are beyond my efforts.' The qualitative findings attest to the view that employees are satisfied with their job at Uganda Breweries-Luzira. 
Table 2: Financial rewards and motivation of employees

\begin{tabular}{llllll}
\hline Indicators of financial rewards & Scale & Freq. & \% & Mean & Std. Dev \\
I receive a salary promptly & Strongly disagree & 56 & 51.4 & & \\
& Disagree & 17 & 15.6 & & \\
& Neutral & 13 & 11.9 & 2.1009 & 1.36045 \\
& Agree & 15 & 13.8 & & \\
My salary matches with my level of & Strongly agree & 08 & 7.3 & & \\
education & Strongly disagree & 06 & 5.5 & & \\
& Disagree & 47 & 43.1 & & \\
& Neutral & 33 & 30.3 & 2.7064 & \multirow{2}{*}{.94578} \\
& Agree & 19 & 17.4 & & \\
My salary tallies with the risks & Strongly agree & 04 & 3.7 & & \\
& Strongly disagree & 00 & 00 & & \\
& Disagree & 28 & 25.7 & & \\
& Neutral & 38 & 34.9 & 3.2477 & \multirow{2}{*}{.96375} \\
& Agree & 31 & 28.4 & & \\
I receive pay benefits on time & Strongly agree & 12 & 11.0 & & \\
& Strongly disagree & 07 & 6.4 & & \\
& Disagree & 23 & 21.1 & & \\
& Neutral & 18 & 16.5 & 3.3670 & 1.15999 \\
& Agree & 45 & 41.3 & & \\
Salary delay is communicated on time & Strongly agree & 16 & 14.7 & & \\
& Strongly disagree & 04 & 3.7 & & \\
& Disagree & 21 & 19.3 & & \\
& Neutral & 21 & 19.3 & 3.5138 & 1.12723 \\
& Agree & 41 & 37.6 & & \\
Extra responsibilities are & Strongly agree & 22 & 20.2 & & \\
accompanied with pay & Strongly disagree & 06 & 5.5 & & \\
& Disagree & 25 & 22.9 & & \\
& Neutral & 23 & 21.1 & 3.3486 & 1.18146 \\
& Agree & 35 & 32.1 & & \\
& Strongly agree & 20 & 18.3 & & \\
& & & &
\end{tabular}

Table 2 reveals that $71 \%$ of the respondents disagreed that they promptly received salary compared to $21.1 \%$ who agreed while $11.9 \%$ were neutral. This suggests that employees do not receive salary uniformly while at work. $48.6 \%$ of the respondents disagreed that their salary matches their education level compared to $21.1 \%$ who disagreed while $30.3 \%$ were neutral, suggesting that salary does not fit individual employee qualifications. Over $39.4 \%$ of the respondents agreed that their salary tallies with the risks compared to $25.7 \%$ who disagreed while $34.9 \%$ were neutral. To a great extent, more than half of the respondents (56\%) agreed to receive pay benefits on time compared to $27.5 \%$ who disagreed while $16.5 \%$ were neutral. Majority of the respondents $(57.8 \%)$ agreed that salary delays is communicated on time compared to $23 \%$ who disagreed while $19.3 \%$ were neutral. This suggests that salary delay is communicated to employees on time at Uganda Breweries-Luzira. Further $51.4 \%$ of the respondents agreed that extra responsibilities are accompanied by pay compared to $21.1 \%$ who were neutral. The cumulative percentages suggest that, to a great extent, financial rewards are fairly administered to employees at Uganda Breweries-Luzira.

The item 'I receive pay benefits on time' was highly rated by respondents (Mean $=3.3670$ ) while the item 'I receive salary promptly' was the lowest-rated (Mean $=2.1009)$. The mean values suggest that employees at Port Bell Luzira are fairly motivated at work. The standard deviations for all the items were low with the highest regarding 'extra responsibilities are accompanied with pat' (Std. Dev. = 1.18146 ) and the lowest regarded the item 'my salary tallies with risks' (Std. Dev $=.94578)$. These statistics suggest that employees have similar opinions about their financial motivation as being fair. These findings support the qualitative findings, especially when an administrative staff was asked about the type of financial motivations given to employees. One of the participants noted that; 'My salary is 
fair, I always do a lot of work to organise and arrange crates of drinks; however, the salary I earn enables me to concentrate fully at work. Additional responsibilities are accompanied with pay'. Another participant noted that; 'I give employees salary promptly. This has affected their work habits since I am motivated to work as expected on the job.' These outcomes do suggest that financial motivation is effectively administered to employees at Uganda Breweries-Luzira.

\section{Description on non-financial motivation of employees at Uganda Breweries}

In this section employees non-financial motivation is described ranging from 5=Strongly Agree, 4=Agree, $3=$ Neutral, $2=$ Disagree and 1=strongly disagree

Table 3. Non-financial motivation rewards

\begin{tabular}{|c|c|c|c|c|c|}
\hline \multirow{6}{*}{$\begin{array}{l}\text { Non-financial motivation } \\
\text { I am always praised at work }\end{array}$} & Scale & Freq. & $\%$ & Mean & Std. Dev \\
\hline & Strongly disagree & 73 & 67.0 & & \\
\hline & Disagree & 15 & 13.8 & & \\
\hline & Neutral & 10 & 9.2 & 1.16697 & 1.13900 \\
\hline & Agree & 06 & 5.5 & & \\
\hline & Strongly agree & 05 & 4.6 & & \\
\hline \multirow[t]{5}{*}{ I am always praised for hard work } & Strongly disagree & 03 & 2.8 & & \\
\hline & Disagree & 28 & 62.4 & & \\
\hline & Neutral & 30 & 16.5 & 2.5413 & .90811 \\
\hline & Agree & 37 & 14.7 & & \\
\hline & Strongly agree & 11 & 3.7 & & \\
\hline \multirow{5}{*}{$\begin{array}{l}\text { My contributions to meetings are } \\
\text { respected }\end{array}$} & Strongly disagree & 03 & 2.8 & & \\
\hline & Disagree & 28 & 25.7 & & \\
\hline & Neutral & 30 & 27.5 & 3.2294 & 1.03309 \\
\hline & Agree & 37 & 33.9 & & \\
\hline & Strongly agree & 11 & 10.1 & & \\
\hline \multirow[t]{5}{*}{ I am delegated with responsibility } & Strongly disagree & 07 & 6.4 & & \\
\hline & Disagree & 23 & 21.1 & & \\
\hline & Neutral & 30 & 27.5 & 3.2293 & 1.11083 \\
\hline & Agree & 36 & 33.0 & & \\
\hline & Strongly agree & 13 & 11.9 & & \\
\hline \multirow{5}{*}{$\begin{array}{l}\text { I am always consulted and my } \\
\text { contribution respected }\end{array}$} & Strongly disagree & 16 & 14.7 & & \\
\hline & Disagree & 09 & 8.3 & & \\
\hline & Neutral & 22 & 20.2 & 3.4679 & 1.44382 \\
\hline & Agree & 20 & 26.6 & & \\
\hline & Strongly agree & 33 & 30.3 & & \\
\hline \multirow[t]{5}{*}{ I am recognised at work } & Strongly disagree & 03 & 2.8 & & \\
\hline & Disagree & 35 & 32.1 & & \\
\hline & Neutral & 35 & 32.1 & 3.0000 & .95258 \\
\hline & Agree & 31 & 28.4 & & \\
\hline & Strongly agree & 05 & 4.6 & & \\
\hline
\end{tabular}

Results from table 3 suggest that the highest number of respondents $(80.8 \%)$ disagreed that they are praised at work compared to $10.1 \%$ who agreed while $16.5 \%$ were neutral. Further, $65.2 \%$ of the respondents disagreed that they are praised for hard work compared to $18.4 \%$ who agreed while 16.5 were neutral. This meant that employees at Uganda Breweries-Luzira are not highly praised at work. However, $44 \%$ of the respondents agreed that their contributions in meetings are respected compared to $28.5 \%$ who disagreed while $27.5 \%$ were neutral. $56.9 \%$ of the respondents agreed that they are always consulted and their contributions respected compared to $22 \%$ who disagreed while $20.2 \%$ were neutral. This meant that employees are adequately consulted while on the job. $34.9 \%$ of the respondents disagreed that they are recognised at work compared to $33 \%$ who agreed while $32.1 \%$ were neutral. These results indicate that employees are not always fully recognised at work. In the main, these results suggest that employee financial motivation is fair at Uganda breweries. Employees rated highest the 
item 'I am always consulted and my contribution respected' (Mean $=3.4679)$ and rated lowest on item "I am always praised at work", mean $=1.6697$. The mean value suggests that to some extent employees are motivated non-financially on the job. The highest standard deviation was on the item "I am always consulted and my contribution respected" std. dev $=1.44382$ and the lowest standard deviation was on the item "I am praised for hard work". The standard deviation in all indicated that employees at Port Bell Luzira had similar views and opinions about their non-financial motivations that it is fair.

These findings tallied well with those of the qualitative findings from interviews held. One of the participants said that employees select colleagues who represent them in meetings held at the university to a great extent. However, we assume the views of those in meetings are a representative of all the employees. Another participant noted, "I always contribute my views and forward them to the central administration and I am happy to see that the central administration was working on them.'

\section{Promotion of employees at Uganda Breweries}

Promotions as the last variable of the independent variable were operationalised into four quantitative items on which employees were requested to self-rating basing on a scale ranging from $1=$ strongly disagree, 2=Disagree, 3=Neutral, 4=Agree and 5=Strongly Agree. Table 4.10 gives results.

\section{Table 4. Indicators on employee promotion}

\begin{tabular}{llllll}
\hline Indicators & Scale & Freq. & \% & Mean & Std. Dev \\
I always receive upward & Strongly disagree & 42 & 38.5 & & \\
promotions & Disagree & 28 & 25.7 & & \\
& Neutral & 03 & 2.8 & 2.4495 & 1.51221 \\
& Agree & 20 & 18.3 & & \\
I respect transfers at work & Strongly agree & 16 & 14.7 & & \\
& Strongly disagree & 09 & 8.3 & & \\
& Disagree & 32 & 29.4 & & \multirow{2}{*}{1.21493} \\
& Neutral & 27 & 24.8 & 3.0734 & 1.21493 \\
Demotions are fairly made at work & Agree & 24 & 22.0 & & \\
& Strongly agree & 17 & 15.6 & & \\
& Strongly disagree & 06 & 5.5 & & \\
& Disagree & 12 & 11.0 & & \\
& Neutral & 39 & 35.8 & 3.4220 & 1.06539 \\
& Agree & 34 & 31.2 & & \\
Promotions are accompanied with & Strongly agree & 18 & 16.5 & & \\
pay & Strongly disagree & 06 & 5.5 & & \\
& Disagree & 20 & 18.3 & & \\
& Neutral & 15 & 13.8 & 3.5505 & 1.18233 \\
& Agree & 44 & 40.4 & & \\
& Strongly agree & 24 & 22.0 & & \\
\hline
\end{tabular}

Table 4 reveals that over $50 \%$ of the respondents $(64.2 \%)$ disagreed that they always receive upward promotion compared to $32 \%$ who agreed with the same while $2.8 \%$ were neutral. Further, $37.7 \%$ of the respondents disagreed that transfers are respected at work compared to 37.6 who agreed while $24.8 \%$ were neutral. This indicates that on average employees disagree that transfers are respected at work. $47.7 \%$ of the respondents agreed that demotions at work are fairly made compared to $16.5 \%$ who disagreed while $35.8 \%$ were neutral. This suggests that demotions are fairly made to employees at Uganda breweries. Over $62.4 \%$ of the respondents agreed that promotions are accompanied by pay compared to $23.8 \%$ who disagreed while $13.8 \%$ were neutral. The cumulative percentages thus reveal that employee promotion is made and fairly administered to employees at Uganda breweries.

\section{Testing of the hypotheses}

The study's first objective was to find out the relationship between financial reward structures and employee satisfaction at Uganda Breweries. 
Table 5. Financial motivation and satisfaction of employees

\begin{tabular}{llll}
\hline \multirow{3}{*}{ Satisfaction } & Satisfaction & Financial motivation \\
& Pearson correlation & 1 & .831 \\
& Sig. (2 tailed) & & .001 \\
& $\mathrm{~N}$ & 109 & 109 \\
Financial motivation & Pearson correlation & .831 & 1 \\
& Sig. (2 tailed) & .001 & \\
& $\mathrm{~N}$ & 109 & 109 \\
\hline
\end{tabular}

Correlation is significant at 0.01

Table 5 reveals the Pearson's correlation coefficient index between financial reward structures and employee satisfaction at Uganda Breweries-Luzira. These findings suggest that there is a significant positive relationship between financial structures and employee satisfaction at the one percent level 2tailed. This suggests that employees who are motivated through adequate salaries, wages and other monetary terms are delighted with the job than any other category.

Table 6. Pearson correlation coefficient between non-financial rewards and employee job satisfaction

\begin{tabular}{llll}
\hline \multirow{3}{*}{ Satisfaction } & Satisfaction & Non-Financial motivation \\
& Pearson correlation & 1 & $.702^{* *}$ \\
& Sig. (2 tailed) & & .000 \\
Non-Financial & N & 109 & 109 \\
motivation & Pearson correlation & $.702 * *$ & 1 \\
& Sig. (2 tailed) & .000 & \\
& $\mathrm{~N}$ & 109 & 109 \\
\hline
\end{tabular}

Correlation is significant at 0.01

Table 6 reveals that the Pearson's correlation coefficient index between non-financial motivation and employees job satisfaction $(r=.702 * *)$ and significant value $(.000<0.05)$. This suggests that there is a significant positive relationship between non-financial structures and employee job structures at the one percent level 2-tailed. Employees who are contented with non-financial motivations are delighted on the job.

Table 7. Employee promotion and satisfaction of employees

\begin{tabular}{llll}
\hline \multirow{5}{*}{ Satisfaction } & Satisfaction & Employee Promotion \\
& Pearson correlation & 1 & $.268^{* *}$ \\
& Sig. (2 tailed) & & .005 \\
& $\mathrm{~N}$ & 109 & 109 \\
Promotion & Pearson correlation & $.268^{* *}$ & 1 \\
& Sig. (2 tailed) & .005 & \\
& $\mathrm{~N}$ & 109 & 109 \\
\hline
\end{tabular}

Correlation is significant at 0.01 level (2-tailed)

Table 7 suggests Pearson's correlation coefficient index between promotions and satisfaction of employees $\left(r=.268^{* *}\right.$ sig. $\left.=.005<0.01\right)$. This implies that there is a highly positive significant relationship between promotions and satisfaction of employees at Uganda breweries-Luzira. However according to the significance values, non-financial reward structures had a greater significant relationship on the satisfaction of employees at Uganda Breweries.

\subsection{Discussions}

The study's first objective was to establish the relationship between financial reward structures and employee job satisfaction at Uganda Breweries-Luzira. The findings reveal a positive significant relationship between financial reward strategies and satisfaction of employees at Uganda Breweries- 
Luzira. These findings are in agreement with other empirical studies and theoretical literature. For instance, the findings are supported by Ng'ethe et al (2012) who suggested that attractive remuneration especially monetary packages are a very important factor of employee satisfaction seeing that it fulfils the financial and material desires. Hong, Hao, Kimar, Ramendran, Kadiresan (2012) agrees with the findings by suggesting that financial motivation involves money awarded to someone as a compensation for injury, loss or suffering, money received by an employee from an employer as salary or wages or $\mathrm{do} /$ give something in return. The findings further agree with the notion that employees contribute to their job satisfaction. Mullins (2010) suggests that employees would be motivated by obtaining the highest possible wages through working most efficiently and satisfyingly. Motivation is a simple issue, what workers want from employers more than anything else is high wages. Mawoli and Babandako (2012) agree with the findings by suggesting that academic staff are highly motivated when the working environment is conducive. Consequently, rational economic needs as a concept of motivation and subsequent motivation approaches have failed the continuing debate about financial rewards as a motivator and their influence on employee job satisfaction.

The study findings are further supported by Jennifer and Gareth (2006) who suggest that managers can choose among several merit pay plans depending on the work employees perform and other considerations since individual jobholders' pay within job categories is determined by factors such as performance, seniority and skill levels. Therefore pay, in the form of salaries and wages, enhances high job satisfaction of employees. This finding was supported by Hong et al (2012) who identified that compensating employees on the job using the money and benefits such as pension, health insurance, retirement plans, allowances provision of company cars for transportation creates high satisfaction opportunities of employees on the job and failure to provide these creates employees to switch to other organisations which provide the same.

Musaazi (2005) who noted that there are three types of rewards which are expressed in monetary terms and administered on employees, these include; wages, salaries and other monetary benefits offered to employees. Effective management of salary encourages and motivates employees, through the job evaluation method and pay data bases organisations/instructions develop a tailored pay and grading framework to meet organisations' needs since competent staff are retained. It suggested here that experienced human resources managers have always known that it takes more than a good salary to attract satisfies. However this study focussed on the management of financial rewards in terms. The study's second objective was to establish the relationship between non-financial reward structures and satisfaction of employees at Uganda Breweries. The study's findings revealed a highly positive significant relationship between non-financial reward structure and employee job satisfaction at Uganda Breweries. These findings were in agreement with the findings of Hong et al (2012) who suggested that intrinsic and non-financial means of motivation that contribute to employee satisfaction includes allowances that include company cars or subsidised transportation. Tibamwenda (2010) in agreement with the study findings includes recognition for achievements, being accorded high status, praising employees and experiencing a sense of accomplishment. The study findings were supported by Heery and Noon (2001) who asserted that to bring about satisfaction, recognition, personal development at work and the social status of such employees are to be improved.

The study findings agreed with Maicibi (2003), who asserted that non-financial remuneration is remunerations that are not paid as part of wages or salaries. The findings suggest a highly positive significant relationship between promotion reward strategies and employees job satisfaction of employees. These findings were in support with those of Shoab et al (2009) who suggested that promotional opportunities refer to the degree an employee perceives his or her chances to grow and be promoted within the organisation. Employees are satisfied to work in jobs that allow them to be promoted to new and challenging positions. The study findings revealed that employees should be given opportunities to grow on the job. These findings were in agreement with Dockel (2003) who argues that people should be rewarded financially and offered opportunities to grow within the organisation. The findings suggest that advancing employees on the job makes them satisfied as earlier suggested by Mpaata (2009) who noted that the way how a worker views the opportunity for advancement is important to how satisfied one is on the job. Promotional opportunities are important to workers job 


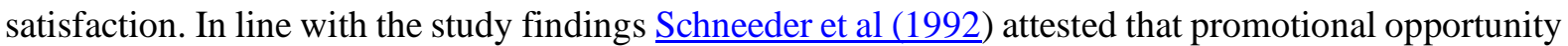
is essential for one's retention. Employees who perceive few opportunities for advancement have negative attitudes towards their work and organisations. It was identified that most employees consider their current jobs as stepping stones for other jobs. The promotion on job is vital if well administered as employees' morale would be improved, efficiency stimulated thereby motivating a staff to stay for work. The promotion staff should be both based on seniority and merit as a criterion and no traces of favouritism. The study findings supported Murgatroyd (1986) who pointed out that promotion of a staff signifies achievement, distinct satisfaction and organisational approval.

\section{Conclusion}

The study findings concluded that financial reward structures have a highly positive significant relationship on satisfaction of employees at Uganda Breweries-Luzira. Further, employees who are paid promptly and communicated to earlier in cases of financial payment delays always get more satisfied on the job. It is resolved that non-financial reward structures have a highly positive significant relationship on employee job satisfaction. Verbal praises, involvement in decision-making, assigning responsibility to individual staff, and satisfaction enhance the job.

\section{Recommendations}

a) There is a need for promotional opportunities in an organisation.

b) A fair and transparent promotional policy is likely to increase on employee performance.

\section{Limitations and study forward}

This study covered Uganda breweries-Luzira, a private company and its findings may not easily be generalised across organisations especially those that are not profit-oriented. From the findings, the following recommendations are made;

a) If employees' satisfaction is to be improved at Uganda Breweries-Luzira, the management of the Branch has to put up strategies to boost employees' financial motivation.

b) Employees should be motivated, non-financially by inviting them to attend in the various meetings held.

c) There should be a fair promotion of employees basing on their experience qualifications and contributions to the company.

\section{Acknowledgement}

The authors wish to acknowledge every respondent and participant's cooperation and participation at Uganda Breweries from whom data were collected.

\section{References}

Adams, J.S. (1963). Wage Inequities, productivity and work quality. A journal o economy and society. Accessed: https://doi.org/10.1111/j.1468-232X.1963.tb00805.X

Apter, M.J., and Boorer, D.R. (1971). The effect of multiple-choice pre-testing on post-test performance in programmed instruction. Programmed learning and educational technology, 8(2). 125-130.

Armstrong, M. (2009). Armstrong's handbook of performance management: an evidence-based guide to delivering high performance. Philadelphia: Kogan publishers.

Banard, B. (2012) Factors that determine academic staff retention and satisfaction in private tertiary institutions in Botswana: An empirical Review. Global advanced research Journal of management and Business studies, 1(9), 278-299.

Cronin, S. N, Becherer, D. (1999). Recognition of staff nurse job performance. Journal of Nurse Administration, 29(1), 26-31.

Desmond, B. F. (2012). Expectancy theory overview. Yale University.

Dockel, A. (2003). The effect of retention factors on organisation commitment. An investigation in high technology employees. Master of Human resource thesis. University of Pretoria.

Green, F. (1996). Skill, training, organisational commitment and unemployment: the economics of a labour management strategy. Centre for Economic Performance, London School of Economics and Political Science. 
Heery, E. \& Noon, M. (2001). A dictionary of human resource management. London: Oxford University Press.

Hong et al (2012). An effectiveness of Human resource management practices on employee satisfaction in Institute of higher learning. A regression analysis. International Journal of Business Research and Management, 3(2), 60-79.

Jennifer, M.G., and Gareth, R.J. (2006). Essentials of contemporary management. McGraw-Hill education.

Kalyango, P., and Eckler, Y., (2010). International journalists' expectations from the US media coverage of hurricane Katrina. Journalism, 11(3), 277-92.

Maicibi, N.A. (2003). Pertinent issues in employees management Kampala. MPK Graphics.

Maicibi, N.A. (2007). Human resource management success Kampala: Makerere University Printery.

Mawoli, M.A. \& Babandako, A.Y. (2011). An evaluation of staff motivation, dissatisfaction and job performance in an academic setting. Australian journal of Business and management research, $1(9), 1-13$.

Mpaata, K.A. (2009), The university job satisfaction challenge and implications to national council for higher education: An empirical evidence, Makerere Journal for Higher Education, 2.

Mullins, L.J. (2010). Management and organisational behaviour. London: Prentice Hall.

Murgatroyd, S. (1986). Management teams and the promotion of staff well-being, School Organisation, 6(1), 115-121.

Musaazi, J. C. S. (2005). Introduction to employee development in Maicibi, N. A. and Nkata, J.L. (2005). Introduction to Human Resource Management: Kampala: Masah Publishers Ltd.

Naris, M.S. \& Ukpere, W. I. (2009). The effectiveness of an HR code. Staff development and training at the polytechnic of Namibia, (3)879-869.

Nawaz, N., Johanian, A. \& Tehreem, S. (2012), Determinants of employee retention in Pakistan international Airlines PIA. European Journal of Business and Management, 4(7) 45-53.

Nelson, et al., (1994). Microsystems in health care: Part 1. Learning from high-performing front-line clinical units.

Ng'ethe, J.M., Iravo, M.E., Namusonge, G.S. (2012). Determinants of academic staff retention and satisfaction. In Kenyan public Universities. Empirical review. International Journal of Humanities and Social Science, 2(3), 205-212.

Ngobeni, E.K. and Bezeuldenhout, A. (2011). Engaging employees for improved retention at higher education institution in South Africa. African Journal of Business and Management, 53, 99619970 .

Nsasolo, B. (2008) Motivation and job satisfaction of employees in monitor publications. Unpublished Master's thesis, Makerere University Kampala Uganda.

Okumbe, J.A. (1999). Education management: theory and practice. Nairobi: Nairobi University Press.

Olasimbo, O.A. (2012) Work family conflict, job satisfaction and labour turnover intentions among state university lecturers-Ogin-state back cock University Nigeria.

Prince, M. (1998). The cross-sectional survey, International Review of Psychiatry, 10(4), 272-277.

Roos, W. (2005). The relationship between employee, motivation job satisfaction and cooperate culture. Pretoria, UNISA.

Sandhya, K. \& Kimar, D.P. (2011), Employee retention by motivation. Indian Journal of Science Technology, 4(12).

Sarantacos (2005) Social science research ( $3^{\text {rd }}$ Edn.) Macmillan Publishers (New York)

Schneider, B. Wheelder, J. K. (1992). The role of the opportunity in the conceptualisation and measurement of job satisfaction. Lexington Books: New York.

Shoaib, M. Noor, A., Tirmizi, S. \& Bashir, S. (2009). Determinants of employee retention in telecom sector in Pakistan.

Tibamwenda, J. (2010). Modern management theories and practices. A productivity and profitability approach. Kampala: Macmillan.

Tung, C., Yin, Y., Zhou, Y., Chang, C., Lin, P., \& Liu, C., (2018). An analysis of healthy workplace accreditation and health promotion efforts based on employees' perspectives, Archives of Environmental \& Occupational Health, 73(5), 322-329.

Ulrich, et al., (1999). Results-based leadership. Harvard Business School Press.

Wertheimer, R.F. (1970). The monetary rewards of migration within the US. Urban institute. 
Xerri, D. (2017). Using questionnaires in teacher research, the clearing house. A Journal of Educational Strategies, Issues and Ideas, 90(3), 65-69. 